\title{
Cephalic secretions of the bumblebee subgenus Sibiricobombus Vogt suggest Bombus niveatus Kriechbaumer and Bombus vorticosus Gerstaecker are conspecific (Hymenoptera, Apidae, Bombus) ${ }^{1}$
}

\author{
Pierre RASMONT ${ }^{a *}$, Michaël TERZO $^{a}$, A. Murat AYTEKIN ${ }^{b}$, Heather HINES $^{c}$, \\ Klara URBANOVA ${ }^{\mathrm{d}, \mathrm{e}}$, L. CAHLIKOVA $^{\mathrm{d}, \mathrm{e}}$, Irena VALTEROVA ${ }^{\mathrm{d} * *}$ \\ a Laboratoire de Zoologie, Université de Mons-Hainaut, B-7000 Mons, Belgium \\ b Department of Biology, Faculty of Science, Hacettepe University, 06532 Beytepe (Ankara), Turkey \\ ${ }^{c}$ Department of Entomology, University of Illinois Urbana-Champaign, 505 S. Goodwin Av., 320 Morrill Hall, \\ Urbana, IL 61801, USA \\ d Institute of Organic Chemistry and Biochemistry, Academy of Sciences of the Czech Republic, Flemingovo 2 \\ 16610 Praha, Czech Republic \\ e Department of Chemistry of Natural Products, Institute of Chemical Technology, Technická 5, 16628 Praha, \\ Czech Republic
}

Received 9 September 2004 - revised 19 February 2005 - accepted 29 April 2005

Published online 19 October 2005

\begin{abstract}
Three taxa of the subgenus Sibiricobombus live in the Near-East mountain steppes: Bombus niveatus, B. sulfureus and B. vorticosus. The latter is also present in the Balkan. B. niveatus and $B$. vorticosus can only be distinguished based on color pattern. B. sulfureus differs in coat color and in genitalia. We identified 40 compounds in the secretions of the labial glands of these taxa, among which 7 were detected for the first time in labial cephalic gland secretions of bumblebee males. Whereas the secretions of the male cephalic labial glands of $B$. sulfureus are very different from those of $B$. niveatus and $B$. vorticosus, we found no significant difference between the latter. We conclude that $B$. sulfureus is a valid species, whereas B. vorticosus is a mere subspecies of B. niveatus: Bombus niveatus ssp. vorticosus Gerstaecker nov. status.
\end{abstract}

cephalic secretions / Sibiricobombus / Bombus / taxonomic status / chemical composition

\section{INTRODUCTION}

Calam (1969) was the first to demonstrate that the secretions of the labial cephalic glands of male bumblebees are highly specific. Since then the cephalic gland secretions of many species have been studied (Bergström and Svensson, 1973a, b; Svensson and Bergström, 1979; Bergström, 1981; Cederberg et al., 1984; Descoins et al., 1984; Bergström et al., 1985; Bertsch, 1997b; Pamilo et al., 1997). These contributions have been reviewed recently by Bergman (1997), Terzo et al. (2003) and Bertsch et al. (2004a, b).

Labial cephalic gland secretions are used as marking pheromones as they are deposited on salient places along the patrolling flights of bumblebees. Charles Darwin originally observed this particular feature of the nuptial behaviour of bumblebees (Freeman, 1968), but the specific character of the patrolling flight has been studied more recently (Frank, 1941; Haas,

* Corresponding author: pierre.rasmont@umh.ac.be

** Corresponding author: irena@uochb.cas.cz

${ }^{1}$ Manuscript editor: Marla Spivak 
1949; Krüger, 1951; Awram, 1970; Bringer, 1973; Svensson, 1979b).

The taxonomy of bumblebees is especially arduous, because so many species are polytypic. Many infra-specific taxa have been regarded as subspecies (Rasmont, 1983) or as mere varieties (Williams, 1991, 1998). Whereas the morphological characters are robust at the level of subgeneric taxonomy (Richards, 1968), they are often too subtle to allow a doubtless identification of species.

The analysis of male marking cephalic secretions has already led to the recognition of two groups of sibling species in the West-Palaearctic region. Bombus (Pyrobombus) lapponicus (Fabricius) s.s. has been separated from B. monticola Smith because of the differences in their marking secretions (Bergström and Svensson, 1973a; Svensson and Bergström, 1977; Svensson, 1979a, 1980). In the same way, it has been determined that Bombus (Bombus) lucorum (L.) includes other taxa, identified by most authors as B. cryptarum (Fabricius) and B. magnus Vogt (Bergström et al., 1973; Rasmont, 1981, 1983; Rasmont et al., 1986; Bertsch, 1997a, b; Pamilo et al., 1997; Urbanova et al., 2001; Valterová et al., 2002; Terzo et al., 2003). On both occasions, a distinction drawn between the composition of the cephalic secretions led to the discovery of ecological, ethological, geographical and even morphological evidence supporting distinctions that had been overlooked before.

The difficulty of defining bumblebee species based on morphological characters and the major role marking secretions play in specificmate recognition system make these insects well suited for the application of Paterson's (1985, 1993) "Species recognition concept". Individuals of the same species are able to search, find and recognise their sexual partners. To study these mechanisms is an attempt to define species along the very criteria applied by the animals themselves.

Some bumblebee groups do not odour mark along patrolling routes. Their nuptial behaviour is different: they watch from rocks or shrubs and attempt copulation with flying females. This is the case with species of the subgenera Mendacibombus Skorikov (Haas, 1976) and Confusibombus Ball (Schremmer, 1972). These bumblebees have very large eyes and this character, as well as their nuptial behaviour, may suggest that, in their case, visual stimuli play the leading role in finding females. However, Hovorka et al. (1998) and Kindl et al. (1999) have determined that males of Bombus confusus Schenck secrete large amounts of pheromones that they use to mark vegetation around their perches. Here again, these cephalic secretions are species specific.

According to Williams (1991), the type of nuptial behaviour is correlated with the structure of vegetation. The well-known patrolling behaviour appears to be more suited to forests and wood edges. Three types of behaviour are specially adapted to open vegetation, "racing" ("each male perches in one small area and will then pursue potential mates from this lookout position, but without competing with other males for preferred perches"), "territorial" (the same as racing but with territorial behavior for perches) and "cruising" (the same as racing but with males hovering rather than perching). The "perching behaviour", described in mendax by Haas (1976) and in confusus by Schremmer (1972) is close to the racing behaviour, and occurs in open surroundings.

Among the West-Palaearctic bumblebees, the species of the subgenus Sibiricobombus Vogt raise interesting questions. They live on steppes and their very large eyes suggest that visual stimuli play a major role in their nuptial behaviour. Nothing is known about their possible marking secretions and their taxonomy is open to debate. The present piece of research is the first study of pheromones in this group of steppe bumblebees.

\section{The West-Palaearctic species of the subge- nus Sibiricobombus Vogt}

Skorikov (1922), Pittioni (1937, 1938), Özbek (1983, 1998), Rasmont (1983), Reinig (1983), Baker (1996) and Rasmont et al. (2000) recognize 3 Sibiricobombus species from the Western Palearctic:

Bombus niveatus Kriechbaumer, 1870 ssp. niveatus

ssp. persiensis (Rasmont, 1983)

Bombus sulfureus Friese, 1905

Bombus vorticosus Gerstaecker, 1872 ssp. vorticosus

ssp. iranensis Pittioni, 1937. 


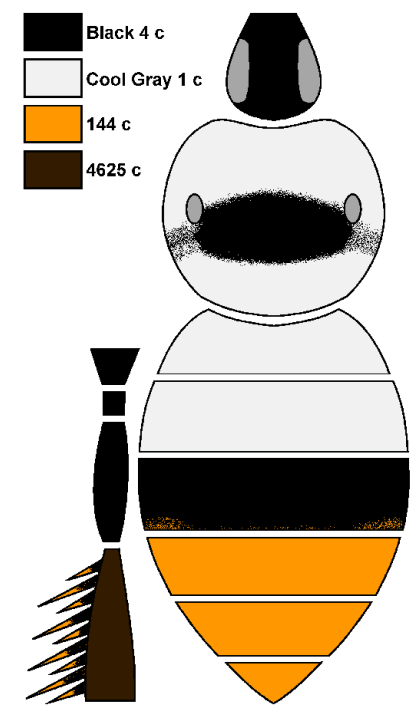

(a)

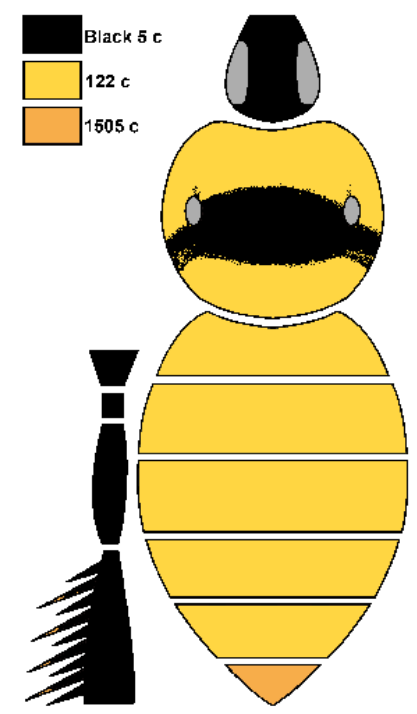

(b)

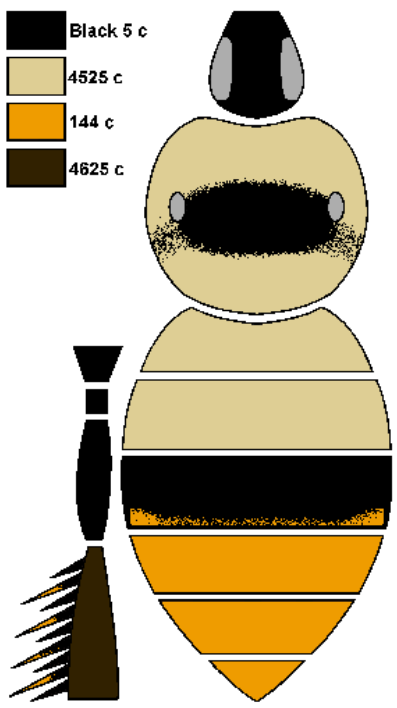

(c)

Figure 1. Colour pattern of West-Palaearctic Sibiricobombus Vogt queens (codes refer to Pantone®). a. Bombus niveatus Kriechbaumer queens. b. Bombus sulfureus Friese. c. Bombus vorticosus Gerstaecker.

Both Bombus niveatus and B. vorticosus have a red-tipped abdomen, the coat stripes being white in the former, yellowish grey in the latter (Fig. 1a, c). There is no morphological difference, other than color pattern, between them, but they have subtle, consistent differences in their genitalia from $B$. sulfureus. The coat of $B$. sulfureus is also quite different, being mainly bright yellow (Fig. 1b). Because of their morphological similarity, Williams (1998) regards $B$. vorticosus and $B$. niveatus as varieties of the same species.

Our goal is to analyse the secretions of the labial glands in these three West-Palaearctic taxa. If secretions are detected, this may indicate that olfactory stimuli play a role in nuptial behaviour. If there is no significant difference between their compositions, it suggests that the taxa may be conspecific. On the contrary, different major compounds would suggest specific isolation.

\section{MATERIALS AND METHODS}

\subsection{Chorology}

The distribution of the three species is based on the following references: Morawitz (1874, 1876),
Table I. Collections examined by P. Rasmont.

\begin{tabular}{lc}
\hline Collections & Specimens \\
\hline Université de Mons-Hainaut & 748 \\
Zoologisches Staatssammlung München & 505 \\
Museum of Zoology Sankt Petersburg & 253 \\
Oberösterreichisches Landesmuseum Linz & 137 \\
Wiering H (Amsterdam) & 40 \\
Aslan M (Mara) & 32 \\
Schwarz M (Ansfelden) & 4 \\
Özbek H (Erzurum) & 3
\end{tabular}

Radoszkowski (1890), Vogt (1909), Fahringer and Friese (1921); Fahringer (1922), Friese (1922), Alfken (1927), Pittioni (1937, 1938, 1940), Atanassov (1939, 1962, 1972a, b, 1974, 1975), Reinig (1939, 1967, 1968, 1971, 1973, 1974), Tkalcu (1969), Baker (1996), Rasmont and Flagothier (1996), Özbek (1998). Many original data have been gathered by the first author (Tab. I). These data are also used to determine the altitudinal range of the species. The distribution maps are drawn with the CFF 2.0 program (Barbier and Rasmont, 2000). 


\subsection{Analysed specimens}

Eighteen males of $B$. niveatus (niv), 3 of B. sulfureus (sul) and 4 of B. vorticosus (vor) were collected in the summer of 2002, in Turkey, by M. Terzo, P. Rasmont, Y. Barbier, H. Hines and M. Aytekin, in the following places (WGS84 coordinates):

Aksaray: Azkarahan, $38^{\circ} 27^{\prime} \mathrm{N} 34^{\circ} 09^{\prime} \mathrm{E} 1200 \mathrm{~m}$ 2.VIII.2003 (vor512, niv514, niv515, niv516, niv517); Kayseri: between Incili and Koçcaz, $38^{\circ} 32^{\prime} \mathrm{N} 35^{\circ} 44^{\prime} \mathrm{E} 1600 \mathrm{~m}$ 4.VIII.2002 (sul529, sul535, vor528, vor534, vor547, niv530-niv533, niv539, niv542-niv546); Erciyes da, near the Tekir baraj, $38^{\circ} 28^{\prime} \mathrm{N} \quad 35^{\circ} 30^{\prime} \mathrm{E} \quad 2000 \mathrm{~m} \quad 3$. VIII.2003

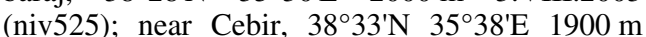
4.VIII.2003 (sul552, niv548, niv550, niv553).

Immediately after collection, we kept males alive separately, for a few hours, in small plastic vials. We then killed them by freezing and immediately dissected them. After removal of the eyes, both parts of the labial cephalic gland of each specimen were placed in a glass vial containing $200 \mu \mathrm{L}$ hexane. The vial was kept for $24 \mathrm{~h}$ at $20^{\circ} \mathrm{C}$, then kept at $-20^{\circ} \mathrm{C}$ until analysis. Each individual and the corresponding extract vial are designated by a unique code and kept at the University of Mons (UMH, Belgium). Parts of the extracts are also kept at the Academy of Sciences of the Czech Republic (IOCB).

\subsection{Chemical analysis}

All specimens have been individually analysed in UMH. Specimens of Bombus niveatus and all specimens of $B$. vorticosus and B. sulfureus were analysed at IOCB for confirmation and detailed compound identification.

The components were identified by gas chromatography/mass spectrometry. The mass spectrometers included ion trap type Finnigan GCQ (UMH) and quadrupole type Fisons MD800 (IOCB). In both laboratories, the column had the following characters: DB-5ms non polar; stationary phase of $(5 \%$ Phenyl)-methylpolysiloxane $0.25 \mu \mathrm{m}$ film thickness; $30 \mathrm{~m}$ length; inner diameter $0.25 \mathrm{~mm}$. The temperature of the injector was $220{ }^{\circ} \mathrm{C}$. The column was initially kept at $70{ }^{\circ} \mathrm{C}$ for $2 \mathrm{~min}$, then warmed at $10{ }^{\circ} \mathrm{C} / \mathrm{min}$ up to $320^{\circ} \mathrm{C}$ and kept at this temperature for $30 \mathrm{~min}$. Helium at a constant speed of $50 \mathrm{~cm} / \mathrm{s}$ (UMH) or a mean flow estimated at $0.7 \mathrm{~mL} / \mathrm{min}$ (IOCB) was used as a carrier gas. Injection was run in the splitless mode.

After injecting $1 \mu \mathrm{L}$ of extract, mass spectra were determined by electron ionisation for molecular masses from 30 to 500 . The position of double bounds was determined by addition of dimethyl disulphide (DMDS) (Francis, 1981) and by chemical ionisation on Varian (ion trap) using acetonitril as the collision gas (Oldham and Svatos, 1999).

\subsection{Statistical analysis}

A data matrix containing specimens (objects) $\times$ compounds (descriptors) was prepared with the concentration values replaced by 0 (absence) or 1 (presence). The data for 12 compounds were deleted from the matrix because they were present in all of the specimens (farnesyl acetate, -springene, ethyl hexadecanoate, henicosane, geranylgeranyl acetate (isom 1), tetracosane, pentacos-9-ene, pentacos-7ene, pentacosane, heptacos-7-ene, nonacosane, dodecyl hexadecanoate). There were 33 remaining descriptors, and a total of 24 objects (specimens).

Using the software NTSYSpc (Rohlf, 1998), five different association matrixes were computed between the specimens (objects) by using the following coefficients: Euclidian, Pearson Phi correlation, taxonomic distance, Chi-square, Manhattan. Three clustering methods were used for each association matrix (objects $\times$ objects): single, complete, UPGMA. Fifteen clusters were thus generated. Only one of these 15 clusters is shown (UPGMA cluster based on Phi Correlation matrix).

\section{RESULTS}

\subsection{Distribution}

Bombus niveatus and B. sulfureus are restricted to the Near East (Figs. 2, 3), whereas $B$. vorticosus is present there but also in the Balkan (Fig. 4). This means that the distributions of B. niveatus and B. vorticosus differ with the exception of a wide sympatry zone in Anatolia and Iran. Pittioni (1937) and Baker (1996) found B. niveatus and B. vorticosus at different altitudes in Iran and concluded that they are separate species. Our own observations indicate that the altitudinal ranges of both taxa are almost identical throughout the Near East (Tab. II). In the Balkan, B. vorticosus lives at lower altitudes, starting at sea level (op. cit.).

Bombus sulfureus is much less common than both the other species: Özbek (1998) found only 3 specimens in two places; our own observations are clearly more numerous. However, we only found 3 males for the present analysis. It appears to be confined to the milkvetch steppes of the Taurus, Elburz, and AraratZagrosian mountains (Fig. 3). The altitudinal range of B. sulfureus in the Near-East is very 


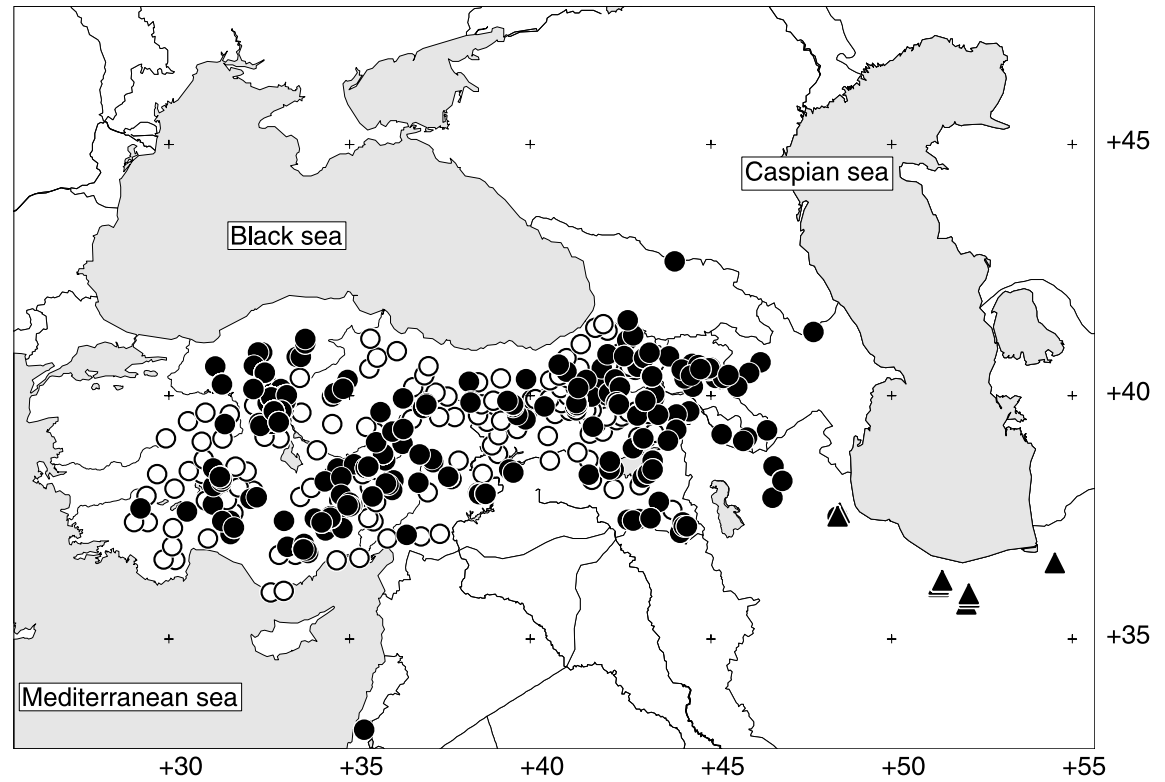

Bombus niveatus from Özbek,1998 146 data

- Bombus niveatus (other data) 1788 specimens

$\Delta$ Bombus niveatus persiensis 59 specimens

Figure 2. Distribution of Bombus niveatus Kriechbaumer.

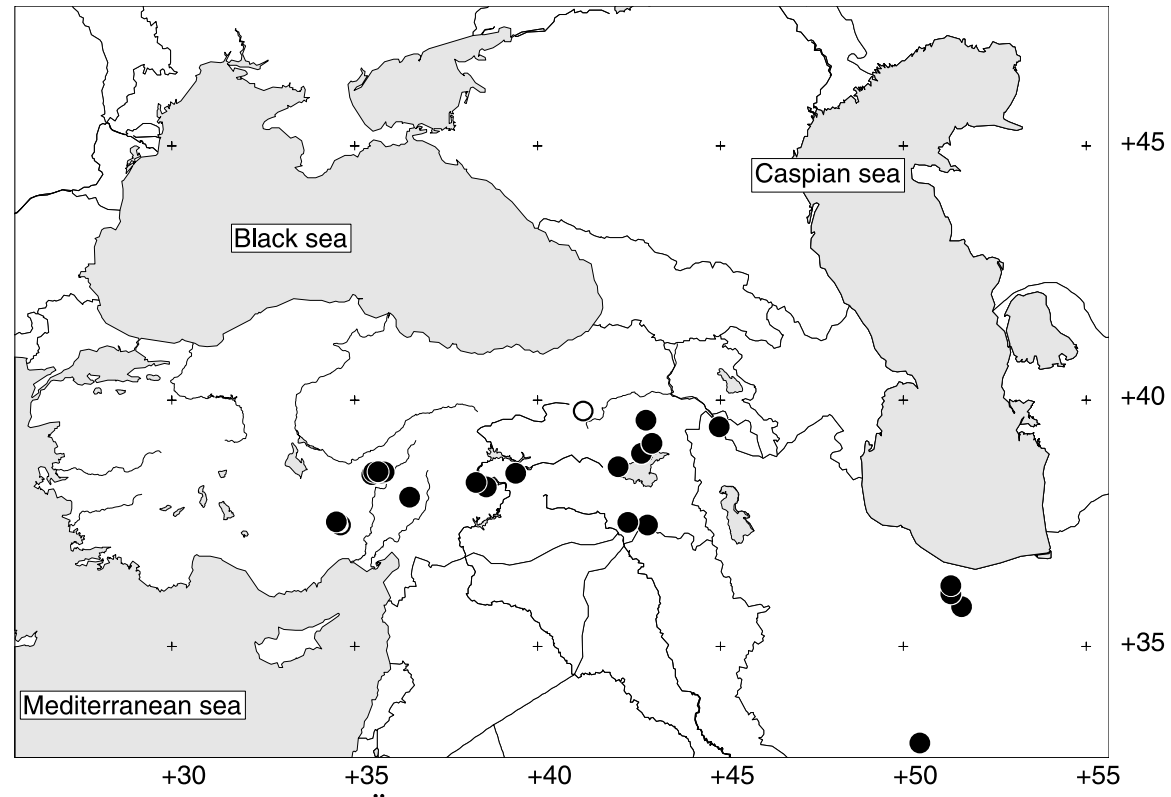

Bombus sulfureus from Özbek,1998 2 data

- Bombus sulfureus (other data) 55 specimens

Figure 3. Distribution of Bombus sulfureus Friese. 


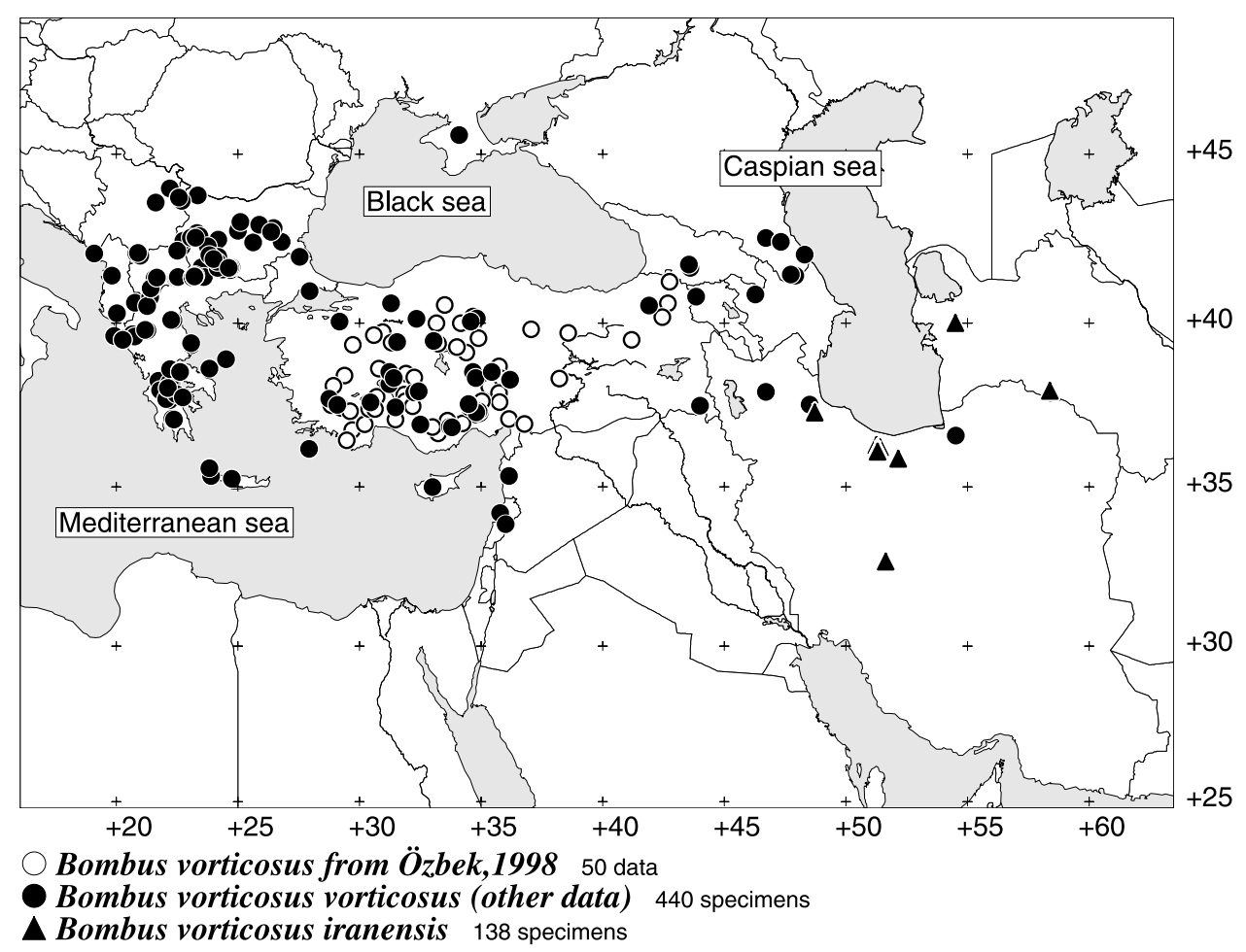

Figure 4. Distribution of Bombus vorticosus Gerstaecker.

Table II. Altitude of West-Palaearctic Sibiricobombus (in m). Turkey, Iran and Caucasus: original data; Balkan: op. cit.

\begin{tabular}{lcccccc}
\hline \multicolumn{1}{c}{ Taxon } & Min & First decile & Mediane & Last decile & Max & N \\
\hline Bombus niveatus & 800 & 950 & 1250 & 2180 & 3000 & 1562 \\
Bombus sulfureus & 1100 & 1600 & 1600 & 2350 & 2500 & 29 \\
$\begin{array}{l}\text { Bombus vorticosus } \\
\text { (Turkey, Iran, Caucasus) }\end{array}$ & 900 & 900 & 1410 & 2000 & 3000 & 126 \\
$\begin{array}{l}\text { Bombus vorticosus } \\
\text { (Balkans) }\end{array}$ & 2 & 630 & 900 & 1500 & 2000 & 195 \\
\hline
\end{tabular}

similar to that of $B$. niveatus and $B$. vorticosus (Tab. II).

\subsection{Nuptial behaviour}

In the three species, the cephalic glands are well developed, leaving no doubt of the use of the marking secretions in nuptial behaviour. The nuptial behaviour of $B$. sulfureus has been observed once by O. Kaftanoglu and P. Rasmont at the Kubbe Geçidi (Turkey, Malatya). This male flew very swiftly, half a meter above the ground, resting very seldom. Both observers were a few tens of meters apart and could not determine whether or not they were watching the same animal. This behaviour was very similar to that described for B. asiaticus, which is also in the subgenus Sibiricobombus, as studied by Williams (1991) in the Himalayas. The nuptial behaviour of $B$. niveatus and B. vorticosus is not known and marking has not been observed. 


\subsection{Chemical analyses}

The compositions of the secretions of the male labial cephalic glands of the three species are summarised in Table III. For B. niveatus and $B$. vorticosus the means are based on the relative percentages of the total peak areas of the individual chromatograms. The data concerning $B$. sulfureus bear on two specimens only: sul 529 and sul 535 . With the third specimen (sul 552), the total ion current in the chromatograph was at least 200 times smaller than with both the others and most of the compounds, except for the principal one, were hardly perceptible and could not be integrated. For both the other specimens, the results differed slightly between laboratories: some peaks could only be detected in Belgium, some others in Czechia. Such small divergences likely resulted from the use of Ion trap GCMS in Belgium as opposed to Quadrupole in Czechia (Hillis and Moritz, 1990). Therefore, we did not present these results as means, but as raw data for both specimens (Tab. III).

A total of 40 compounds were identified in B. niveatus and B. vorticosus (Tab. III) and they were the same in both taxa. The means for these taxa have been compared and tested with a Student's $t$ test and we found no significant difference. It may be concluded that both taxa have the same cephalic secretions.

As for B. sulfureus (Tab. III), 22 compounds were identified, 18 of which were common with $B$. niveatus/B. vorticosus. The four remaining compounds are: tricosane, geranylgeranyl acetate (isomer 2), tetracosene and heptacos-11-ene. The main compound is the same in the three taxa (geranylgeranyl acetate, isomer 1) and occurs in similar concentrations (74\% in B. niveatus and from 76 to $83 \%$ in $B$. sulfureus). Among the remaining major compounds - i.e. those corresponding to peaks with a relative area greater than $1 \%$ - only dodecyl hexadecanoate and pentacosane are common to B. niveatus and B. sulfureus. Discrimination by females of both taxa likely rely on the presence or absence of the other major compounds. These are tricosane (4-5.6\%) and pentacosene $(0.9-4.1 \%)$ in B. sulfureus against geranylgeraniol (13\%) and heptacosane $(1.5 \%)$ in $B$. niveatus.

\subsection{Statistical analysis}

Among the 15 clusters obtained, all combine both specimens of B. sulfureus in a distant branch. On the contrary, the 4 specimens of B. vorticosus are always contained within the branch that includes the 19 specimens of $B$. niveatus. One of the 15 clusters is shown in Figure 5.

\section{DISCUSSION}

Among all the compounds identified in the present work, seven have never been found in the cephalic labial gland secretions of bumblebee males (Terzo et al., 2003; Bertsch et al. 2004a, b): decyl acetate, dodecyl decanoate, geranylgeranyl butyrate, dodecyl dodecanoate, geranylgeranyl hexanoate, dodecyl hexadecanoate, dodecenyl octadecenoate.

Springenes are remarkable aliphatic diterpenes. The $\beta$-springene was first discovered by Zimmermann in the secretion of the dorsal glands of the antelope Antidorcas marsupialis (Burger et al., 1978), and later in the secretions of cloacal glands of crocodiles (Weldon et al., 1988; Avery et al., 1993), in the Dufour glands of ants (Billen et al., 1988), braconid wasps (Fukushima et al., 1990), and stingless bees (Cruz-Lopez et al., 2001) and in the essential oils of the leaves of Heracleum persicum Desf. (Mojab et al., 2002). Recently, springenes have been found in the male cephalic labial gland secretions of the bumblebee Bombus griseocollis De Geer (Bertsch et al., 2004b).

Decyl acetate has also been found as part of the cuticular hydrocarbons of Bombus norvegicus Sparre Schneider (Zimma et al., 2003). This compound could be part of the repellent allomone used by this inquiline species against the workers of Bombus hypnorum during nest usurpation. It is notheworthy that Bombus norvegicus is not known as an inquiline of any Sibiricobombus. It is also curious that the same compound (decyl acetate) could act as a repellent against Bombus hypnorum but act as a sexual attractant for Sibiricobombus.

While decyl acetate, dodecyl decanoate, dodecyl dodecanoate, dodecyl hexadecanoate and dodecenyl octadecenoate have not previously been found in any bumblebee males, 
Table III. Composition of the male cephalic labial gland secretions of West-Palaearctic species of the subgenus Sibiricobombus. Relative proportions of compounds in order of their retention times (RT). Grey cells identify the major compounds.

\begin{tabular}{|c|c|c|c|c|c|c|c|c|}
\hline \multirow[b]{2}{*}{ Compounds } & \multirow{2}{*}{$\begin{array}{c}\text { RT } \\
\text { in min }\end{array}$} & \multicolumn{2}{|c|}{$\begin{array}{l}\text { B. niveatus } \\
(18 \text { spec.) }\end{array}$} & \multicolumn{2}{|c|}{$\begin{array}{l}\text { B. vorticosus } \\
\text { (4 spec.) }\end{array}$} & \multicolumn{3}{|c|}{$\begin{array}{l}\text { B. sulfureus } \\
\text { (2 spec.) }\end{array}$} \\
\hline & & Mean & Sdt-dev & Mean & Std-dev & $\mathrm{t}$ student & sul529 (\%) & $\operatorname{sul535(\% )}$ \\
\hline Decyl acetate & 12.87 & 0.03 & 0.04 & 0.02 & 0.03 & 0.86 & - & - \\
\hline Farnesyl acetate & 15.42 & 0.07 & 0.03 & 0.05 & 0.02 & 1.01 & traces & traces \\
\hline$\beta$-Springene & 16.24 & 0.03 & 0.01 & 0.03 & 0.03 & 0.32 & traces & traces \\
\hline$\alpha$-Springene & 16.55 & 0.02 & 0.01 & 0.02 & 0.01 & 0.37 & traces & traces \\
\hline Ethyl hexadecanoate & 16.75 & 0.05 & 0.02 & 0.03 & 0.01 & 1.56 & traces & traces \\
\hline Unidentified terpene & 16.84 & 0.01 & 0.01 & 0.01 & 0.02 & 0.10 & - & - \\
\hline Nonadecene & 17.05 & 0.01 & 0.00 & 0.01 & 0.01 & 0.91 & - & - \\
\hline Unidentified terpene & 17.81 & 0.01 & 0.03 & 0.06 & 0.13 & 0.85 & - & - \\
\hline Henicosane & 18.08 & 0.07 & 0.06 & 0.03 & 0.03 & 1.57 & 0.14 & 0.61 \\
\hline Unidentified compound & 18.50 & 0.06 & 0.07 & 0.04 & 0.06 & 0.47 & - & - \\
\hline Unidentified terpene & 18.72 & 0.03 & 0.04 & 0.06 & 0.08 & 0.67 & 0.12 & 0.70 \\
\hline Ethyl octadecenoate & 18.82 & 0.01 & 0.02 & 0.01 & 0.01 & 0.68 & traces & traces \\
\hline Unidentified terpene & 18.88 & 0.03 & 0.07 & 0.01 & 0.01 & 1.11 & - & - \\
\hline Geranylgeraniol & 18.96 & 13.53 & 3.00 & 12.77 & 5.80 & 0.25 & - & - \\
\hline Geranylgeranial & 19.14 & 0.12 & 0.16 & 0.12 & 0.11 & 0.05 & - & - \\
\hline Tricos-9-ene & 19.61 & traces & - & traces & - & - & 1.32 & - \\
\hline Tricos-7-ene & 19.67 & 0.12 & 0.17 & 0.10 & 0.10 & 0.29 & - & - \\
\hline Geranylgeranyl acetate (isom. 1) & 19.93 & 74.03 & 6.01 & 74.40 & 6.58 & 0.10 & 82.84 & 76.24 \\
\hline Tricosane & 19.88 & - & - & - & - & - & 3.99 & 5.60 \\
\hline Geranylgeranyl acetate (isom. 2) & & - & - & - & - & - & traces & Traces \\
\hline Tetracosene* & 20.51 & - & - & - & - & - & 0.27 & - \\
\hline Dodecyl decanoate & 20.52 & 0.10 & 0.06 & 0.06 & 0.03 & 1.57 & - & - \\
\hline Tetracosane & 20.76 & 0.08 & 0.04 & 0.09 & 0.02 & 0.58 & 0.13 & 2.33 \\
\hline Geranylgeranyl butyrate & 21.32 & 0.02 & 0.02 & 0.03 & 0.02 & 0.37 & - & - \\
\hline Pentacos-9-ene & 21.38 & 0.21 & 0.08 & 0.22 & 0.09 & 0.21 & 4.09 & 0.86 \\
\hline Pentacos-7-ene & 21.44 & 0.12 & 0.04 & 0.11 & 0.03 & 0.78 & 0.33 & 1.97 \\
\hline Pentacosane & 21.59 & 2.59 & 1.00 & 2.36 & 0.74 & 0.53 & 3.30 & 3.74 \\
\hline Dodecyl dodecanoate & 22.15 & 0.31 & 0.20 & 0.21 & 0.10 & 1.44 & - & - \\
\hline Hexacosane & 22.38 & 0.10 & 0.05 & 0.09 & 0.03 & 0.59 & 0.14 & - \\
\hline Heptacos-11(?)-ene & 22.97 & - & - & - & - & - & 0.40 & 0.85 \\
\hline Heptacos-9-ene & 22.98 & 0.28 & 0.13 & 0.27 & 0.08 & 0.14 & 0.12 & - \\
\hline Heptacos-7-ene & 23.04 & 0.16 & 0.07 & 0.14 & 0.05 & 0.91 & 0.83 & 1.42 \\
\hline Heptacosane & 23.16 & 1.63 & 0.99 & 1.43 & 0.45 & 0.62 & - & - \\
\hline Geranylgeranyl hexanoate & 23.53 & 0.09 & 0.04 & 0.10 & 0.06 & 0.30 & - & - \\
\hline Dodecyl tetradecanoate & 23.68 & 0.17 & 0.10 & 0.15 & 0.11 & 0.30 & - & - \\
\hline Octacosane & 23.91 & 0.07 & 0.05 & 0.07 & 0.03 & 0.27 & - & - \\
\hline Nonacos-9-ene & 24.48 & 0.22 & 0.10 & 0.23 & 0.10 & 0.15 & - & - \\
\hline Nonacos-7-ene & 24.54 & 0.16 & 0.07 & 0.15 & 0.06 & 0.13 & - & - \\
\hline Nonacosane & 24.65 & 0.92 & 0.72 & 0.86 & 0.36 & 0.24 & 0.29 & 1.65 \\
\hline Unidentified wax ester & 25.02 & 0.08 & 0.08 & 0.10 & 0.08 & 0.28 & - & - \\
\hline Dodecyl hexadecanoate & 25.13 & 3.98 & 1.69 & 4.96 & 1.99 & 0.92 & 1.72 & 4.03 \\
\hline
\end{tabular}


Table III. Continued.

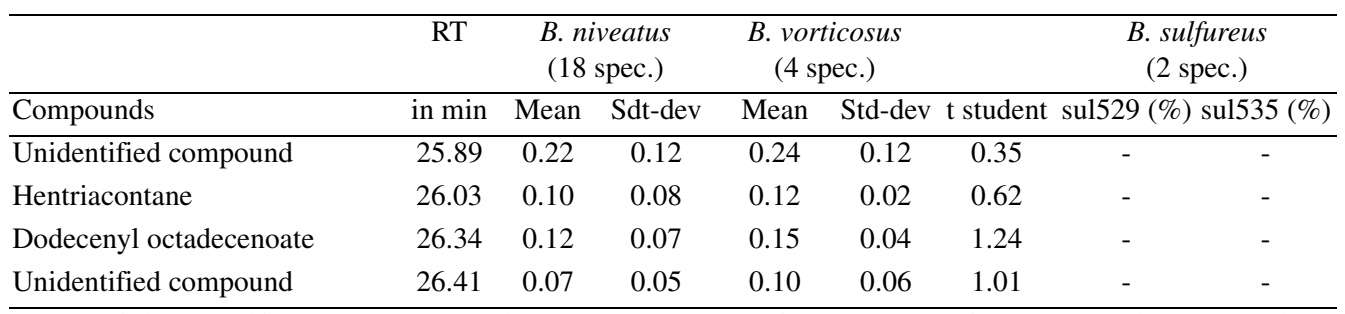

Traces of 6 unidentified compounds (mainly terpenes) at RT 15.83, 17.40, 18.50, 19.29, 20.60 and 21.26 are found in few specimens only of B. niveatus or B. vorticosus and traces of an unidentified compound at RT 18.50 is found in sul529 only. Traces of 9-nonadecene, 9-tricosene, 7-tricosene and 9-hentriacontene are detected through dimethyl disulfide adduction. They are not considered in this table.

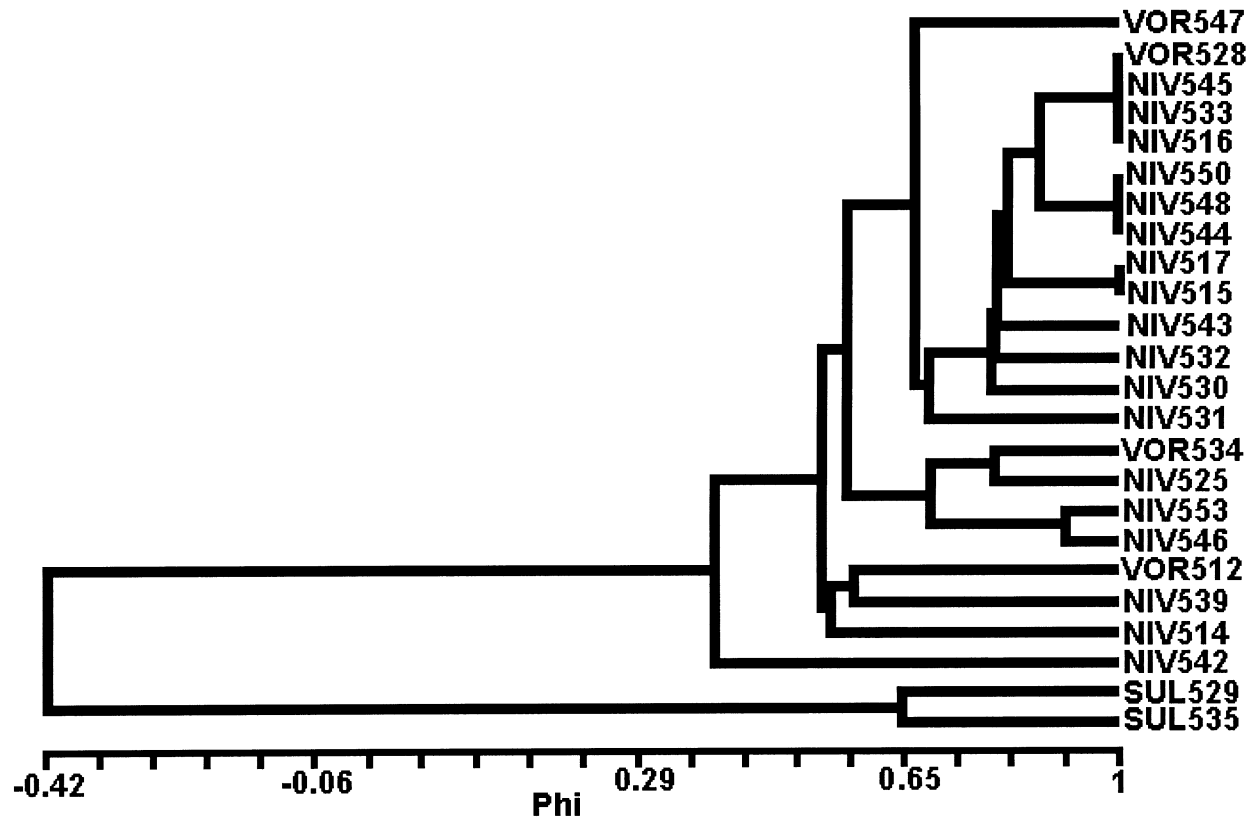

Figure 5. UPGMA cluster of the specimens association matrix. The association matrix used here is Pearson Phi correlation.

these compounds have been found in labial glands secretions in Bombus terrestris queens (Hefetz et al., 1996). Most of these compounds can also be found in mandibular glands, tarsal glands and the Dufour's gland.

It is worth noting that in the bumblebees of the subgenus Sibiricobombus studied here, the relative concentration of terpenes is higher than that of the other compounds (even when the principal compound is omitted). On the other hand, the non-terpenic compounds are esters or simple fatty acids and contain no alcohols. Up to now, alcohols have been encountered in most bumblebees species studied (Terzo et al., 2003).

Most authors regard $B$. sulfureus as a valid species, quite distinct from $B$. niveatus and B. vorticosus (Reinig, 1971; Rasmont, 1983; Baker, 1996; Özbek, 1998; Williams, 1998). The comparison of the male cephalic labial 
gland secretions of these taxa points to the same conclusion. Many of these authors regard $B$. niveatus and $B$. vorticosus as distinct species too. Among all the recent authors, Williams (1998) is the only one to question this opinion: regarding both taxa as conspecific. Baker (1996) admits that both taxa are very similar but stresses two points to separate the taxa: no specimen with an intermediate coloration has ever been encountered and both taxa live at different altitudes. Regarding the first statement, Williams (1998) suggests that this situation could also result from a di-allelic determination of colour patterns. As for the second statement, our own numerous data show that throughout the Near East, B. niveatus and B. vorticosus are found at the same altitudes (Tab. II). In the Balkan, where only $B$. vorticosus is present, this taxon lives at lower altitudes.

Our analyses show that the secretions of the male cephalic glands are identical in both taxa and the large size of the glands suggests that these secretions could be used as marking pheromones. If it is accepted that the composition of these cephalic secretions are species specific (op. cit.), B. niveatus and B. vorticosus should be considered conspecific. The priority binome is Bombus niveatus Kriechbaumer.

We cannot exclude the possibility that the same compounds occur in two different species by way of convergent evolution. However, we have found B. niveatus and B. vorticosus together at the same field site, foraging on the same flowers. Also no morphological character aside from color pattern can be found for separating them. It seems therefore very unlikely that the great similarity of the cephalic secretions of these taxa could be explained by the convergent evolution of two different species.

Even with a wide zone of sympatry, the distributions of both taxa are appreciably different. For this reason, we propose to maintain provisionally vorticosus Gerstaecker as a subspecies of B. niveatus. The status of iranensis Pittioni and persiensis (Rasmont) remains to be settled but these are likely to be mere forms of B. niveatus.

The nomenclature advocated here for the West-Palaearctic species of the subgenus Sibiricobombus is:

Bombus (Sibiricobombus) niveatus Kriechbaumer, 1870:158 ssp. niveatus

ssp. vorticosus Gerstaecker, 1872:290

Bombus (Sibiricobombus) sulfureus Friese, 1905:521.

As a general conclusion, the "species recognition concept" has proven very fruitful in the systematics of bumblebees. Up to now, the analysis of male cephalic labial gland secretions has facilitated the discovery or supported the existence of previously unknown or disregarded species. Reciprocally, the same concept has allowed us for the first time to suggest that two taxa, previously regarded as valid species may be conspecific.

\section{Credits}

Analysed specimens have been collected by A.M. Aytekin, Y. Barbier, H. Hines, P. Rasmont and $\mathrm{M}$. Terzo. The identification of all specimens, data base management and mapping have been made by P. Rasmont. Field trips have been managed by A.M. Aytekin. Specimens were prepared by M. Terzo. Quantitative analyses have been made by M. Terzo. Identification of the compounds has been performed by I. Valterova, with the help of K. Urbanova and L. Cahlikova.

\section{ACKNOWLEDGEMENTS}

Authors thank Y. Barbier, S. Cameron, M. Campo, E. Diller, D. Flagothier, R. Flammang, F. Güsenleitner, O. Kaftanolu, Yu.A. Pesenko, M. Schwarz, for their help in collecting specimens and data. They also thank the following field collectors: W. Aigner, M. Aslan, S. Blank, M. Bryanskj, M. De Freina, K. Denes, M. Halada, M. Malyuzhenko, M. Oorschot, H. Özbek, A. Rasmont, L. and W.F. Reinig, K. Warncke, H. Wiering.

This research has been mainly funded by the Fonds National de la Recherche Scientifique de Belgique and by the Fonds de la Recherche Fondamentale et Collective. M. Terzo was employed as Postdoctoral Researcher by this institution. Most observations made in Turkey have been made thanks to a N.A.T.O. project to O. Kaftanolu. The contribution of H. Hines is funded by U.S.D.A. (NRICGP-2002-35302-11553) grant to S. Cameron. The chemical contribution was done in the framework of the research project Z4 0550506 (Academy of Sciences of the Czech Republic) and supported financially by the Grant Agency of the Czech Republic (grant No. 203/02/0158) and the Grant Agency of the Academy of Sciences of the Czech Republic (grant No. A4055403). All 
these financial contributors are gratefully acknowledged.

Résumé - Les secrétions céphaliques du sousgenre Siricobombus Vogt (Hymenoptera : Apidae) suggèrent que Bombus niveatus Kriechbaumer et B. vorticosus Gerstaecker sont conspécifiques. Il n'est pas possible d'identifier avec précision les espèces de bourdons d'après leurs caractères morphologiques ou leurs couleurs. Par contre, les phéromones secrétées par les glandes labiales des mâles sont fortement spécifiques et bien adaptées à la définition d'une espèce basée sur le concept de reconnaissance d'espèces. Les taxons présentant les mêmes combinaisons de phéromones labiales peuvent être considérés comme conspécifiques (= de la même espèce).

Les auteurs ont ré-examiné le statut d'espèce de bourdons de la zone paléarctique occidentale appartenant au sous-genre Siricobombus Vogt: Bombus niveatus, B. sulfureus et B. vorticosus. Ces trois taxons vivent de préférence dans les steppes de montagne : $B$. niveatus et $B$. sulfureus se limitent au Proche-Orient (Figs. 2, 3), B. vorticosus est également présent dans les Balkans (Fig. 4). B. niveatus et $B$. vorticosus ne peuvent être différenciés morphologiquement que par la coloration et ne diffèrent de $B$. sulfureus que par la couleur du pelage et par des caractères mineurs des genitalia (Fig. 1).

Parmi les 40 composés que nous avons identifiés dans les secrétions des glandes labiales, sept le sont pour la première fois. Les trois taxons du sous-genre Sibiricobombus diffèrent de tous les autres par une concentration en terpènes relativement plus grande que celle des autres composés et par le fait que les composés non terpéniques se limitent à des esters et à des acides gras simples.

Alors que les secrétions des glandes céphaliques des mâles de $B$. sulfureus sont très différentes de celles de $B$. niveatus et $B$. vorticosus, nous n'avons pas trouvé de différence significative entre ces dernières (Tab. III). Nous en concluons que $B$. sulfureus est une espèce valable, tandis que $B$. vorticosus n'est qu' une sous-espèce de B. niveatus: Bombus niveatus ssp. vorticosus Gerstaecker nov. status.

Sibiricobombus / Bombus / secrétions céphalique / composition chimique / statut taxonomique

Zusammenfassung - Die Kopfsekrete der Hummeluntergattung Sibiricobombus Vogt legen nahe, dass Bombus niveatus Kriechbaumer und Bombus vorticosus Gerstaecker zur gleichen Art gehören (Hymenoptera, Apidae, Bombus). Es ist nicht möglich, alle Hummelarten nur anhand ihrer morphologischen Eigenschaften oder Färbungen zu bestimmen. Im Gegensatz dazu sind die von den Labialdrüsen abgegebenen Pheromone der Männchen hochgradig artspezifisch und daher zur Abgrenzung der Arten auf Basis des Arterkennungs- konzeptes gut geeignet. Taxa mit identischen Labialdrüsenpheromonen können daher als gleiche Arten angesehen werden. Auf dieser Grundlage haben die Autoren den Artstatus der Westpaläarktischen Hummeln der der Untergattung Sibiricobombus angehörenden Arten Bombus niveatus, B. sulfureus and $B$. vorticosus neu untersucht. Diese drei Taxa leben vorzugsweise in den Bergsteppen. B. niveatus und $B$. sulfureus sind im Nahen Osten heimisch (Abb. 2, 3), während $B$. vorticosus auch im Balkan vorkommt (Abb. 4). B. niveatus und B. vorticosus können nur morphologisch anhand des Färbungsmusters unterschieden werden (Abb. 1) und unterscheiden sich von $B$. sulfureus nur in der Behaarungfarbe (Abb. 1) und in geringfügigen Details der Genitalien.

Sieben der von uns identifizierten 40 Komponenten der Labialdrüsensekrete wurden zum ersten Mal in diesen Drüsen der Hummelmännchen gefunden. Die drei Taxa der Gattung Sibiricobombus unterscheiden sich von allen anderen Hummeln durch relativ höhere Konzentrationen von Terpenen im Vergleich zu den anderen Komponenten und durch auf Ester und einfache Fettsäuren beschränkte nicht-terpenische Komponenten.

Während die Sekrete der männlichen Labialdrüsen von $B$. sulfureus sich sehr stark von denen von $B$. niveatus und $B$. vorticosus unterscheiden, fanden wir keine signifikanten Unterschiede zwischen den letztgenannten Arten (Tab. III). Wir schließen daraus, dass $B$. sulfureus eine gültige Art ist, während $B$. vorticosus nur eine Unterart von $B$. niveatus darstellt: Bombus niveatus ssp. vorticosus Gerstaecker nov. status.

Kopfsekrete / Sibiricobombus / Bombus / taxonomischer Status / chemische Zusammensetzung

\section{REFERENCES}

Alfken J.D. (1927) Apidae, in: Roemer C.F., Zoologische Streifzuge in Attika, Morea und besonders auf der Insel Kreta. I, Abh. Naturwiss. Ver. zu Bremen 26, 442.

Atanassov N. (1939) Prinos' k'm' izuchavane faunata na zemnit' pcheli (Bombus, Hym.) v' B'lgariya Beitrag zum Studium der Hummelfauna Bulgariens, Mitt. Bulg. Entomol. Ges. Sofia 10, 91-109 [1938].

Atanassov N. (1962) Izsledvaniya vyrkhu sistematikata $i$ ekologiyata na vidove Hymenoptera ot rajona na gr. Petrich (Yuz Bylgariya), Izvestiya na zoologicheskiya Institut s Muzej 12, 109-172.

Atanassov N. (1972a) Vidove Hymenoptera ot zpadna Stara planina. Chast I, Izvestiya na Zoologicheskiya Institut s Musej 35, 179-228.

Atanassov N. (1972b) Vidove Hymenoptera ot zpadna Stara planina. Chast II, Izvestiya na Zoologicheskiya Institut s Musej 36, 23-59. 
Atanassov N. (1974) Zemni pcheli (Bombus Latr. i Psithyrus Lep., Hym.) ot sredna i iztochna Stara Planina - Hummeln und Schmarotzerhummeln (Bombus Latr., Psithyrus Lep., Hym.) von dem mittleren und dem östlichen Balkangebirge, Izvestiya na zoologicheskiya Institut s Muzej 41, $107-121$.

Atanassov N. (1975) Vidov s'stav i razprostranenie na Bombus Latr. i Psithyrus Lep. (Hymenoptera) v Rodopite - Artenzummansetzung und Vertbreitung der Bombus Latr. und Psithyrus Lep. (Hymenoptera) in den Rhodopen, Fauna na Rodopite, Materiali - La Faune des Rhodopes, Matériaux, Acad. Bulg. Sci. Sofia 10, 145-160.

Avery J.W., Shafagati A., Turner A., Wheeler J.W., Weldon P.J. (1993) Beta-springene in the paracloacal gland secretions of the smoothfronted caiman (Paleosuchus trigonatus), Biochem. Syst. Ecol. 21, 533-534.

Awram W.J. (1970) Flight route behaviour of bumblebees, Ph.D. Thesis, University of London.

Baker D.B. (1996) On a collection of humble-bees from northern Iran (Hymenoptera: Apoidea, Bombinae), Beitr. Entomol. Berlin 46, 109-132.

Barbier Y., Rasmont P. (2000) CFF-Edit version 2.0., Guide d'utilisation, Université de Mons-Hainaut, Mons.

Bergman P. (1997) Chemical communication in bumblebee premating behaviour, Ph.D. Thesis, Göteborg University, Göteborg.

Bergström G. (1981) Complexity of exocrine signals in Aculeate Hymenoptera, in: Les phéromones sexuelles et les médiateurs chimiques chez les insectes, Coll. INRA n ${ }^{\circ} 3$, Colmar, 25-27 novembre 1980, Paris, INRA, pp. 35-47.

Bergström G., Svensson B.G. (1973a) Studies on natural odoriferous compounds. VIII. Characteristic marking secretions of the forms lapponicus and scandinavicus Fabr. (Hymenoptera, Apidae) by analysis of the volatile marking secretion from individual males, Chem. Scr. 4, 231-238.

Bergström G., Svensson B.G. (1973b) 2,3-dihydro-6, trans-farnesol: main component in the cephalic marker secretion of Bombus jonellus K. (Hym., Apidae) males, Zoon Suppl. 1, 61-65.

Bergström G., Kullenberg B., Ställberg-Stenhagen S. (1973) Studies on Natural Odoriferous Compounds. VII. Recognition of two forms of Bombus lucorum L. (Hymenoptera, Apidae) by analysis of the volatile marking secretion from individual males, Chem. Scr. 4, 174-182.

Bergström G., Appelgren M., Svensson B.G., Ågren L., Descoins C., Frerot B., Gallois M., Lettere M. (1985) Marking pheromones of Megabombus sylvarum (L.) and M. ruderarius (Müller) males (Hymenoptera: Apidae), Apidologie 16, 57-68.

Bertsch A. (1997a) Wieviele Arten der Untergattung Terrestribombus (Hymenoptera, Apidae) gibt es in Nordhessen; die Abgrenzung von Bombus cryptarum und B. lucorum mittels männlicher Labialdrüsen-Sekrete und morphologischer Merkmale, Marburger Entomol. Publ. 2, 1-28.
Bertsch A. (1997b) Abgrenzung der Hummel-Arten Bombus cryptarum und B. lucorum mittels männlicher Labialdrüsen-Sekrete und morphologischer Merkmale (Hymenoptera, Apidae), Entomol. Gen. 22, 129-145.

Bertsch A., Schweer H., Titze A. (2004a) Analysis of the labial gland secretions of the male bumblebee Bombus perplexus Cresson (Hymenoptera: Apidae) from North America, Z. Naturforsch. 59c, 263-270.

Bertsch A., Schweer H., Titze A. (2004b) Analysis of the labial gland secretions of the male bumblebee Bombus griseocollis (Hymenoptera: Apidae), Z. Naturforsch. 59c, 701-707.

Billen J.P.J., Jackson B.D., Morgan E.D. (1988) Secretion of the Dufour gland of the ant Nothomyrmecia macrops (Hymenoptera: Formicidae), Experientia 44, 715-719.

Bringer B. (1973) Territorial flight of bumble-bee males in coniferous forest on the northernmost part of the island of Öland, Zoon Suppl. 1, 15-22.

Burger B.V., Maritha le Roux H.S.C.S., VeronaTruter R.C.B. (1978) Mammalian pheromone studies-III, (E,E)-7,11,15-trimethyl-3-metylenehexadeca-1,6,10,14-tetraene, a new diterpene analogue of $b$-farnesene from the dorsal gland of springbok Antidorcas marsupialis, Tetrahedron Lett. 52, 5221-5224.

Calam D.H. (1969) Species and sex-specific compounds from the heads of male bumblebees (Bombus spp.), Nature 221, 856-857.

Cederberg B., Svensson B.G., Bergström G., Appelgren M., Groth I. (1984) Male marking pheromones in north European cuckoo bumble bees, Psithyrus (Hymenoptera, Apidae), Acta Univ. Ups. Ser. V:C 3, 161-166.

Cruz-Lopez I., Flavia E., Patricio L.R.A., Morgan E.D. (2001) Secretion of stingless bees: the Dufour gland of Nonnatrigona testaceicornis, J. Chem. Ecol. 27, 69-80.

Descoins C., Frerot B., Gallois M., Lettere M., Bergström G., Appelgren M., Svensson B.G., Ågren L. (1984) Identification des composés de la phéromone de marquage produite par les glandes labiales des mâles de Megabombus pascuorum (Scopoli) (Hymenoptera, Apidae), Acta Univ. Ups. Ser. V:C 3, 149-152.

Fahringer J. (1922) Hymenopterologische Ergebnisse einer wissenschaftlichen Studienreise nach der Türkei und Kleinasien (mit Auschluss des Amanusgebirges), Arch. Naturg. 88A, 149-222.

Fahringer J., Friese H. (1921) Eine HymenopterenAusbeute aus dem Amanusgebirge (Kleinasien und Nord-Syrien, südl. Armenien), Arch. Naturg. 87A, 150-176.

Francis G.W. (1981) Alkylthiolation for the Determination of Doublebond Positions in Unsaturated Fatty Acid Esters, Chem. Phys. Lipids 29, 369-374.

Frank A. (1941) Eigenartige Flugbahnen bei Hummelmännchen, Z. Vgl. Physiol. 28, 467-484.

Freeman R.B. (1968) Charles Darwin on the routes of male humble bees, Bull. Br. Mus. (Nat. Hist.) (Hist. Ser.) 3, 177-189. 
Friese H. (1905) Neue oder wenig bekannte Hummeln des russischen Reiches (Hymenoptera), Ann. Mus. Zool. Acad. Imp. Sci. St. Petersbourg 9, 507-523 (1904).

Friese H. (1922) Eine Kriegsausbeute an Apiden (Bienen) aus Makedonien, Zool. Jahrb. Abt. Syst. $46,175-216$.

Fukushima J., Kuwamara Y., Yamada A., Suzuki T. (1990) New non-cyclic homo-diterpene from the sting glands of Bracon hebetor Say (Hymenoptera, Braconidae), Agric. Biol. Chem. 54, 809810 .

Gerstaecker A. (1872) Hymenopterologische Beiträge 1-5. Stett, Entomol. Z. 33, 250-308.

Haas A. (1949) Arttypische Flugbahnen von Hummelmännchen, Z. Vgl. Physiol. 31, 281-307.

Haas A. (1976) Paarungsverhalten und Nestbau der alpinen Hummelart Bombus mendax (Hymenoptera: Apidae), Entomol. Germ. 3, 248-259.

Hefetz A., Taghizadeh T., Francke W. (1996) The exocrinology of the queen bumble bee Bombus terrestris (Hymenoptera: Apidae, Bombini), Z. Naturforsch. 51c, 409-422.

Hillis D.M., Moritz C. (1990) Molecular systematics, Sinauer Ass. Inc., Sunderland, Massachusetts.

Hovorka O., Urbanova K., Valterova I. (1998) Premating behavior of Bombus confusus males and analysis of their labial gland secretion, J. Chem. Ecol. 24, 183-193.

Kindl J., Hovorka O., Urbanova K., Valterova I. (1999) Scent marking in male premating behavior of Bombus confusus, J. Chem. Ecol. 25, 14891500.

Krüger E. (1951) Über die Bahnflüge der Männchen der Gattungen Bombus und Psithyrus (Bombidae, Hymenoptera), Z. Tierpsychol. 8, 62-75.

Mojab F., Rustaiyan A., Jasbi A.M. (2002) Essential oils of Heracleum persicum Desf. ex Fischer leaves, Daru 10, 6-8.

Morawitz F. (1874) Die Bienen Daghestans, Trudy Russkago Entomologicheskago Obshchestva 10, 129-189.

Morawitz F. (1876) Zur Bienenfauna der Caucasusländer, Trudy Russkago Entomologicheskago Obshchestva 12, 3-69.

Oldham N.J., Svatos A. (1999) Determination of the double bond position in functionalized monoenes by chemical ionization ion-trap mass spectrometry using acetonitrile as a reagent gas, Rapid Commun. Mass Spectrom. 13, 331-336.

Özbek H. (1983) Dogu Anadolu'nun Bazi Yörelerindeki Bombinae (Hymenoptera: Apoidea, Bombidae) Türleri Üzerinde Taksonomik ve Bazi Biyolojik Çalismalar, Ata. Üniv. Yay. 621, 1-70.

Özbek H. (1998) On the bumblebee fauna of Turkey: II. The genus Pyrobombus (Hymenoptera, Apidae, Bombinae), Zool. Middle East 16, 89-106.

Pamilo P., Tengö J., Rasmont P., Pirhonen K., Pekkarinen A., Kaarnama E. (1997) Pheromonal and enzyme genetic characteristics of the Bombus lucorum complex in the Northern Europe, Entomol. Fenn. 7, 187-194.
Paterson H.E.H. (1985) The recognition concept of species, in: Vrba E.S. (Ed.), Species and speciation, Trans. Mus. Monog. 4, 21-29.

Paterson H.E.H. (1993) Evolution and the recognition concept of species, Collected writings, Johns Hopkins University Press, Baltimore.

Pittioni B. (1937) Eine Hummelausbeute aus dem Elburs-Gebirge (Iran), Konowia Wien 16, 113129.

Pittioni B. (1938) Die Hummeln und Schmarotzerhummeln der Balkan-Halbinsel mit besonderer Berücksichtigung der Fauna Bulgariens. I: Allgemeiner Teil, Mitt. Naturwiss. Ins. Sofia 11, 12-69.

Pittioni B. (1940) Analytische Untersuchungen an den Hummelfaunen des Witoscha- und LjulinGebirges in Bulgarien, Mitt. bulg. entomol. Ges. in Sofia 11, 101-137.

Radoszkowski O. (1890) Hyménoptères récoltés sur le Mont Ararat, Trudy Russkago Entomologicheskago Obshchestva 24, 502-510.

Rasmont P. (1981) Redescription d'une espèce méconnue de bourdon d'Europe : Bombus lucocryptarum Ball, 1914 n. status (Hymenoptera, Apidae, Bombinae), Bull. Ann. Soc. R. Belge Entomol. 117, 149-154.

Rasmont P. (1983) Catalogue commenté des bourdons de la région ouest-paléarctique (Hymenoptera, Apidae, Bombinae), Notes Faun. Gembloux 7, 172 .

Rasmont P., Flagothier D. (1996) Biogéographie et choix floraux des bourdons (Hymenoptera, Apidae) de la Turquie. N.A.T.O.-O.T.A.N. TUPollination project, rapport préliminaire, Université de Mons-Hainaut, Adana Çukurova Universitesi.

Rasmont P., Scholl A., de Jonghe R., Obrecht E., Adamski A. (1986) Identité et variabilité des mâles de bourdons du genre Bombus Latreille sensu stricto en Europe occidentale et centrale (Hymenoptera, Apidae, Bombinae), Rev. Suisse Zool. 93, 661-682.

Rasmont P., Verhaeghe J.-C., Rasmont R., Terzo M. (2000) West-Palaearctic bumblebees, in: Sommeijer M.J., De Ruijter A. (Eds.), Insect pollination in greenhouses: proceedings of the specialists' meeting held in Soesterberg, The Netherlands, 30 September to 2 October 1999 , Universiteit Utrecht, Utrecht, pp. 93-97.

Reinig W.F. (1939) Die Hummeln der Reisen von E. Pfeiffer (1936) und E. Pfeiffer und Dr. W. Forster (1937) in den Elburs, Mitt. Münch. Entomol. Ges. 29, 145-148.

Reinig W.F. (1967) Zur Kenntnis der Hummelfaunen einiger Gebirge West-Kleinasien (Hym., Apidae), Nachrichtenblatt der Bayer. Entomol. 16, 81-91.

Reinig W.F. (1968) Über die Hummeln und Schmarotzerhummeln Nordwest-Anatoliens (Hym., Apidae), Nachrichtenblatt. Bayer. Entomol. 17, 101-112.

Reinig W.F. (1971) Zur Faunistik und Zoogeographie des Vorderen Orients. 3. Beitrag zur Kenntnis der Hummeln und Schmarotzerhummeln Anatoliens, 
Veröffentlichungen der Zool Staatssamml. Münch. 15, 139-165.

Reinig W.F. (1973) Faunistische und zoogeographische Studien in Kleinasien. 4. Beitrag zur Kenntnis der anatolischen Hummeln (Bombus Latr., 1802) und Schmarotzerhummeln (Psithyrus Lep., 1832) (Hym., Apidae), Mitt. Münch Entomol. Ges. 69, 110-133.

Reinig W.F. (1974) Zur Verbreitung einiger Hummelarten auf der Balkan-Halbinsel (Hym., Bombidae), Nachrichtenblatt Bayer. Entomol. 23, 11-13.

Reinig W.F. (1983) Synopsis der in Europa nachgewiesenen Hummel- und Schmarotzerhummelarten (Hymenoptera, Bombidae), Spixiana, München 4, 159-164.

Richards O.W. (1968) The subgeneric divisions of the genus Bombus Latreille (Hymenoptera, Apidae), Bull. Br. Mus. (Nat. Hist.) (Entomol. Ser.) 22, 211-276.

Rohlf F.J. (1998) NTSYSpc 2.02g. Numerical Taxonomy and Multivariate Analysis System, Applied Biostatistics Inc., New York.

Schremmer F. (1972) Beobachtungen zum Paarungsverhalten der Männchen von Bombus confusus Schenck, Z. Tierpsychol. 31, 503-512.

Skorikov A.S. (1922) Shmeli paleartiki. Chast I. Obshchaya biologiya (so vklyucheniem zoogeografii) [Les bourdons de la faune paléarctique. Partie I. Biologie générale (la zoogéographie y compris)], Izvestiya Severnoi Oblastnoi Stantsii Zashchity Rastenii ot Vreditelei 4, 1-160, 17 maps.

Svensson B.G. (1979a) Pyrobombus lapponicus auct., in Europe recognized as two species: P. lapponicus (Fabricius, 1793) and P. monticola (Smith, 1849) (Hymenoptera, Apoidea, Bombinae), Entomol. Scand. 10, 275-296.

Svensson B.G. (1979b) Patrolling behaviour of bumble bee males in a subalpine/alpine area, Swedish Lapland, Zoon 7, 67-94.

Svensson B.G. (1980) Species-isolating mechanisms in male bumble bees (Hymenoptera, Apidae), Acta Univ. Upps. 549, 1-42.

Svensson B.G., Bergström G. (1977) Volatile marking secretions from the labial gland of North European Pyrobombus D.T. Males (Hymenoptera, Apidae), Insectes Soc. 24, 213-224.
Svensson B.G., Bergström G. (1979) Marking pheromones of Alpinobombus males, J. Chem. Ecol. 5, 603-615.

Terzo M., Valterova I., Urbanova K., Rasmont P. (2003) De la nécessité de redécrire les phéromones sexuelles des mâles de bourdons (Hymenoptera, Apidae, Bombini) publiées avant 1996 pour leur utilisation en analyse phylogénétique, Phytoprotection 84, 39-51.

Tkalcu B. (1969) Ergebnisse der Albanien-Expedition 1961 des Deutschen Entomologischen Institutes. 78. Beitrag. Hymenoptera: Apidae IV (Bombinae), Beitr. Entomol. 19, 887-916.

Urbanova K., Valterova I., Hovorka O., Kindl J. (2001) Chemotaxonomical characterisation of males of Bombus lucorum (Hymenoptera: Apidae) collected in the Czech Republic, Eur. J. Entomol. 98, 111-115.

Valterová I., Urbanová K., Rasmont P., Terzo M. (2002) Marking pheromones of bumblebees: composition of the labial gland secretion of males of Bombus magnus (Hymenoptera, Apoidea, Bombini), in: Proc. 19th Annual Meeting Int. Soc. Chem. Ecol., August 3-8, 2002, Hamburg, Germany.

Vogt O. (1909) Studien über das Artproblem. 1. Mitteilung. Über das Variieren der Hummeln. I. Teil. Schriften der Berlinischen Gesellschaft Naturforschender Freunde, Berlin 1909, pp. 28$84,1 \mathrm{pl}$.

Weldon P.J., Shafagati A., Wheeler J.W. (1988) Lipids in the paracloacal gland of the American alligator (Alligator mississippiensis), Lipids 23, 727 .

Williams P.H. (1991) The bumble bees of the Kashmir Himalaya (Hymenoptera: Apidae, Bombini), Bull. Br. Mus. (Nat. Hist.) (Entomol. Ser.) 60, 1-204.

Williams P.H. (1998) An annotated checklist of bumble bees with an analysis of patterns of description (Hymenoptera: Apidae, Bombini), Bull. Nat. Hist. Mus. (Nat. Hist.) (Entomol. Ser.) 67, 79-152.

Zimma B.O., Ayasse M., Tengö J., Ibarra F., Schulz C., Francke W. (2003). Do social parasitic bumblebees use chemical weapons? (Hymenoptera, Apidae), J. Comp. Physiol. A 189, 769-775. 